\title{
Saulės energijos paklausos didinimo prielaidos
}

\author{
Audronė Kleviené $\dot{1}^{1}$ \\ Eugenijus Perednis ${ }^{2}$ \\ ${ }^{1}$ Lietuvos energetikos institutas, \\ Regionu energetikos \\ pletros laboratorija, \\ Breslaujos g. 3, \\ LT-44403 Kaunas \\ ${ }^{2}$ Lietuvos energetikos institutas, \\ Atsinaujinančiu energijos \\ šaltiniu laboratorija, \\ Breslaujos g. 3, \\ LT-44403 Kaunas \\ El.paštas: audrone@mail.lei.lt; \\ saule@mail.lei.lt
}

Tyrimu analizuojamos prielaidos - didinti atsinaujinančių energijos išteklių paklausą saulès energijos panaudojimo pavyzdžiu. Pagrindinis akcentas yra vartotojų pasigamintos šilumos, panaudojant saulès energijos technologijas, ekonominio konkurencingumo galimybių analizè. Parodoma, kokiu mastu ir kokiomis prielaidomis saulès energijos technologijos galètų konkuruoti su kitais energijos šaltiniais, jų išoriniu naudingumu apibrèžiant galimus finansavimo šaltinius.

Raktažodžiai: saulès energija, metodinis sprendimas, naudingumo ekonominis vertinimas

\section{IVADAS}

Straipsnyje išdèstome tyrimo, kuris vykdomas pagal Lietuvos mokslo tarybos finansuojamą projektą „Atsinaujinančių energijos išteklių paklausos ekonominio skatinimo pagrindimas" tarpinius rezultatus. Ivertiname tariamai pačios „brangiausios“ - saulès energijos technologijų - panaudojimo perspektyvumą. Keliame hipotezę, kad saulès energija mažai tepanaudojama ne tik trūkstant ekonominès paramos. Daug svaresnè priežastis yra nepakankamas organizuotumas, visuomenès švietimo ir žinių sklaidos spragos, pernelyg dideli lūkesčiai valstybès paramai gauti. Dažniausiai žinios kaupiamos ir perteikiamos susiaurintu požiūriu - vieni faktai akcentuojami, kiti nutylimi. Pvz., egzistuoja nuomonè, kad saulès šiluminès energijos dèka pagamintos energijos ekonominis potencialas Lietuvoje yra nedidelis dèl brangių technologijų ir netinkamų klimatinių sąlygų. Ši faktą paneigia tai, kad panašaus klimato šalyse, pvz., Vokietijoje, Danijoje ir kt. šalia kitų atsinauji- nančios energijos rūšių veržliai ir sparčiai plètojama saulès energetika.

Vyriausybès dokumentuose vis dar stokojama didesnio dėmesio saulès energijos panaudojimo galimybėms. Be abejo, siekiant, kad ši energijos rūšis Lietuvoje būtų naudojama intensyviau, yra būtina efektyvi valstybès parama, kuri sudarytu prielaidas konkurencingai energijos, pagamintos naudojant saulès spinduliuotę, kainai. Tačiau reikia nepamiršti labai svarbų tiek teoriniu, tiek praktiniu atžvilgiais momentą - rinka netrikdomai gali veikti tik tada, kai priimami sprendimai yra teisingi ir vienodi visiems rinkos dalyviams. Rinkos dalyviai yra ne tik energijos gamintojai, bet ir vartotojai. Ekonominiu požiūriu energijos tiekejjai remtini tiek ir tokiu mastu, kiek reikia suvienodinti išorinių išlaidų dydžius, o tuo būdu ir pasiūlos lygị. Vartotojai remtini todèl ir tik tokia apimtimi, kuri leidžia suvienodinti naudingumo lygị. Naudingumas gali būti ịvertintas ne tik pavienio vartotojo, bet ir visuomenès pažiūriu. Geriausia parama yra paklausos didinimas, o gamintojai ir tiekejai 
turi konkuruoti tarpusavyje ne dèl kvotų, bet dèl savo tiekiamos produkcijos mažesnès kainos.

Pigumas ar brangumas yra laikini reiškiniai, labiausiai priklausantys nuo masiškumo panaudojant technologijas. Pvz., Europoje pastebima ryški santykinès saulès karšto vandens sistemų kainos mažèjimo tendencija. Ji nuo 1995 iki 2006 metų sumažèjo apie $40 \%$ ir siekè 3300-3500 Lt/kWš, prognozuojama, kad ateityje (iki 2025 m.) juc kaina turètų nukristi iki 1500-1600 Lt/kWš. Lietuvoje kainos siekia apie 2500-3 $100 \mathrm{Lt} / \mathrm{kW}_{\breve{s}}$. Tai yra augančios paklausos rezultatas, kuris leidžia gausèti gamintojų ir tiekejjų skaičiui, didina konkurenciją, skatina technologinę pažangą.

Žvelgiant iš vartotojų pozicijų, taigi, paklausos požiūriu, saulès energijos panaudojimas galimas tik kartu su kitais energijos ištekliais. Todèl saulès energijos panaudojimo planavimas (subjektų: atskiro namo, centralizuoto šilumos tiekimo įmonès, o idealiu atveju ir miesto) turètu būti vykdomas tokiu būdu, kad neatsirastų takoskyra tarp investicijų vartotojo ir gamintojo (tiekèjo).

\section{METODINIS IŠORINIO NAUDINGUMO EKONOMINIO VERTINIMO PRINCIPAS}

Ekonominè teorija paaiškina esminę priežastį, kodèl rinkoje nèra tam tikrų prekių ir paslaugų (nors jos labai naudingos visuomenei) pakankamos paklausos. Priežastis ta, kad sukuriama išorinė prekès ir paslaugos teikiama nauda neatsispindi tiesioginèse rinkos operacijose, o tuo pačiu ir kainoje [2]. Atsinaujinančių energijos išteklių (AEI) atžvilgiu - tai yra ypatingai svarbus momentas. AEI vartojimo teikiama išorinė aplinkosauginè nauda yra bene geriausias išorinès naudos pavyzdys. Naudojant AEI mažinama neigiama ittaka aplinkai, taupomi organinio kuro ištekliai, issisavinamos naujos technologijos. Paklausa atsinaujinantiems energijos ištekliams rinkoje neatspindi paminètos visuomenei aktualios naudos, kuri gaunama vartojant gaminamą iš AEI energiją. Nauda išsisklaido tarp ịvairių vartotojų, kuriais galima ịvardinti asmenis, ateities kartas, miestus, kompanijas. Žmonès, nedalyvaujantys rinkos transakcijose, kartais gali gauti nemokamai dali prekés teikiamos naudos.

1 pav. pavaizduota vadinamosios „žaliosios“, t. y. iš atsinaujinančiu energijos išteklių pagamintos elektros pasiūlos kreivè $S$, kuri apima „žaliosios“ energijos gamybos išlaidas. Tai įrengimų, naujų technologijų i̇sisavinimo išlaidos, darbuotojų atlyginimai, taip pat išlaidos darbuotojų apmokymui bei jų kvalifikacijos kèlimui ir kt.

Jeigu nežinoma ar tiesiog neịvertinama išorinè nauda, susijusi su „žaliosios“ energijos vartojimu, vartotojai pasirinks perkamos energijos apimtis pagal $D_{1}$ paklausos kreivę. „Žaliosios" elektros bus nuperkama mažiau nei būtų pagrịsta ekonomiškai, t. y. kiekis $Q_{1}$ vietoj kiekio $Q_{2}$. Tačiau pirkdami iš AEI pagamintą, vadinamąją „žaliąją " elektrą, jie mažina aplinkos taršą, ir tai pajunta visi gyventojai: išvengia ligu ir kitụ neigiamų pasekmių dèl užterštos aplinkos. Ši nauda neatsispindi paklausos $D_{1}$ kreiveje. Todèl ir kaina nusistovi taške $P_{1}$, t. y. ji mažesné, nei būtų îvertinus tikrajji žaliosios energijos naudingumą Tokiu atveju kaina nusistovètu taške $a$ ir atitinkamai galètų pakilti iki $P_{2}$ lygio, taigi, žaliosios energijos būtų superkama daugiau. Paklausos kreivè turètų būti $D_{2}$, kur ši išoriné nauda yra ịvertinta. Pagrindinè problema - įskaičiuoti naudą i ekonominių rodikliu išraišką. Tokiu atveju produkcijos $Q_{1}$ kiekį būtų galima realizuoti už kainą $P_{3}$.

Kiekvieno papildomo elektros vieneto ribinè nauda nuo $Q_{1}$ iki $Q_{2}$ kiekio viršija ribinius ju gamybos kaštus, o išorinè nauda, pavaizduota trikampiu $a b c$, yra nerealizuojama ir vaizduoja rinkos neefektyvumą. Pažymime, kad nauda gali būti žinoma, deklaruojama, bet tas žinojimas nepaverčiamas konkrečiais praktiniais skaičiavimų ịrankiais. Vis dèlto nepakanka ir įtikinamų skaičiavimų. Reikia daug didesnių struktūrinių pokyčių, kad AEI ịsisavinimo procesas prasidètų, o juo labiau, kad taptų masiniu. Būtent žinios tampa šio proceso pagrindine varomąja jèga.

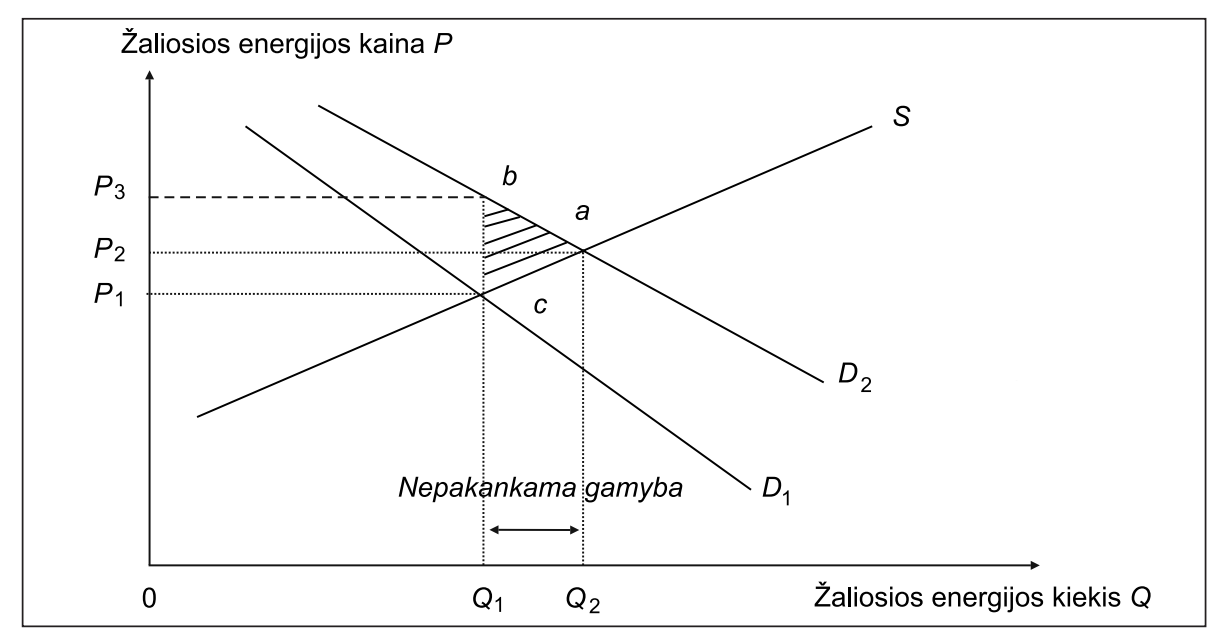

1 pav. Išorinès naudos j̨vertinimo galima j̨taka AEl paklausai 
Apibendrinant galima pasakyti, kad neįvertinus išorinès AEI panaudojimo naudos, konkurencinè rinka gamins žaliąją energiją taške $c$, kur kertasi rinkos pasiūlos $S$ ir paklausos $D_{1}$ kreivés. Šiame taške nusistovės rinkos pusiausvyros kaina $P_{1}$, o gaminamos žaliosios energijos kiekis sieks $Q_{1}$. Tačiau jei ne tik privati, bet ir išorine nauda būtu įvertinta, nusistovètų nauja pusiausvyros kaina rinkoje $P_{2}$, o žaliosios energijos gamybos apimtys išaugtų iki $Q_{2}$, kur ribinè nauda susilygintų su ribiniais kaštais. Visuomenès gaunama nauda pažymèta trikampiu $a b c$.

Šios teorinès nuostatos igyvendinimui galima panaudoti sugretinamos energijos kainos metodą. Primename, kad sugretinama elektros kaina (SEK) yra tokia energijos kaina, kuri turètų būti nustatyta, kad esant pasirinktai (nustatytai) diskonto normai, lygiai kapitalo kainai, visos diskontuotos išlaidos yra lygios pajamoms, t. y. grynoji dabartinè verté (GDV) lygi nuliui.

Šis metodas yra labai parankus, nes jame galima koncentruoti pagrindinius kriterijus - grynąją dabartinę vertę (ji lygi nuliui), vidinę grąžos normą (kadangi ją numatome). Pagrindinis pranašumas, kad ši rodikli galima sugretinti su konkurencine energijos kaina susiklosčiusioje rinkoje. Kitaip tariant, sugretinamoji kaina rodo, kad projektas turès, pvz., $10 \%$ vidinę grąžos normą (tokią numatome) tuo atveju, jeigu šios elektrinès (ar bet kurio kito gamintojo / tiekèjo) pateikiamos energijos kaina nebus žemesnẻ nei ta, kuri gaunama pagal formulę:

$$
K_{s}=\sum_{i=1}^{i=n} \frac{\left(I_{i}+e_{i}-Z_{i}\right)}{\left(1+r_{n}\right)^{i}} / \sum_{i=1}^{i=n} \frac{G_{i}}{\left(1+r_{n}\right)^{i}},
$$

čia: $I_{i}$ - kapitalinès investicijos; $e_{i}$ - metinès eksploatacijos ir aptarnavimo išlaidos; $Z_{i}$ - išorinis atsinaujinančios energijos gamybos naudingumas (bendroje sumoje gali igyti neigiamą ženklą); $r$ - numatomas periodinis diskonto santykis (diskonto norma); $n$ - tarnavimo amžius (metais); $i$ - metų eilès numeris; $G_{i}$ - metinè pasigamintos ir panaudotos energijos apimtis; $r_{n}$ - numatoma diskonto norma (atsinaujinantiems energijos ištekliams ši diskonto norma gali būti mažesnè nei iškastiniam kurui).

Šiuo metodu galima vertinti labai platų spektrą i̇vairių variantų ir gautą rezultatą, pvz., $1 \mathrm{kWh}$ sugretinamą energijos kainą galima lyginti su esama oficialiai patvirtinta kaina ir spręsti apie projekto priimtinumą.

Galima nustatyti SEK pagal ịvairius bet kurio analizuojamo objekto (buto, namo, miesto, rajono ir kt.) energetikos ūkio raidos scenarijus, kaip kompoziciją iš esamų galingumų rekonstrukcijos, naujų jègainių statybos, mikro- ir mini- termofikacinių jègainių, vietinių ir atsinaujinančiųjų energijos ištekliu panaudojimo bei kitus variantus. Kiekvienas galimų scenarijų kompozicijos elementų sąlygoja papildomas išlaidas (arba išvengiamus nuostolius), kurios ekonomiškai įvertinamos principine investicijų pagal scenarijus vertinimo formule [1].

Kalbant apie saulès energijos panaudojimo perspektyvas, akivaizdu, kad pagrindinè rinka yra vartotojų pusèje. Svarbiausia problema, lemianti vartotojų lètą AEI ịsisavinimo procesą, yra žinių ir organizuotumo stoka, atbaidantys investicijų dydžiai. Būtina atkreipti dèmesî, kad pagrindinis kriterijus yra ne kolektoriaus ir jo montavimo kaina, bet šilumos, kuri gaunama panaudojant kolektorių ir naudingai suvartojama, vieneto kaina. Yra įmanoma ir netgi būtina ịvertinti, kiek kainuos būstui - individualiam šeimos namui ar daugiabučiam daugelio savininkų namui - pagaminta šiluma naudojant vienokio ar kitokio tipo kolektorių. Šis metodas leidžia nustatyti ekonomines visų techninių aspektų projekcijas ị šilumos vieneto sugretinamą kainą. Jeigu būtų išsamiau ịvertinta ekologinẻ ir ekonominẻ bei socialinè nauda ilgalaikiu periodu ir tuo pagrindu būtų teikiama ekonominè parama vartotojams, pasigaminantiems energiją naudojant saulès energiją, paklausa pažangioms saulès technologijoms akivaizdžiai išaugtų.

\section{SAULĖS ENERGIJOS PANAUDOJIMO EKONOMINIS VERTINIMAS}

\section{Saulès energijos panaudojimo galimybių tyrimai}

Nepriklausomybès laikotarpiu atlikta daug tyrimų, susijusiu su saulès energijos panaudojimu. Jau pirmojoje Nacionalineje energijos vartojimo efektyvumo programoje $1991 \mathrm{~m}$. buvo pradèta kaupti informaciją apie esamas galimybes ir padarytos kai kurios praktinès išvados bei pateiktos rekomendacijos apie saulès energijos panaudojimo galimybes žemès ūkyje, pramonèje bei namu ūkiuose. Buvo puoselèjamos viltys remtis savos gamybos technologine baze [3, 4]. Vèliau tyrimai intensyvèjo ir ịvairejo. Viena svarbesniu tyrimo krypčiu yra saulès energijos panaudojimas gyvenamuju namu patalpu šildymui $[5,6]$. Jau pakankamai gerai žinomas potencialas, ištyrinètos įvairios saulès energijos panaudojimo sritys $[7,8]$. Buvo pagrista, kad artimiausiu metu platesnị mastą gali igyti saulès energijos panaudojimo kryptis - karšto vandens paruošimo sistemos. Tačiau svarbiausia, kad iš esmès jau yra susikūrusi infrastruktūra bei yra gana daug sektinos praktikos pavyzdžiu $[9,10]$. Vykdydami Lietuvos mokslo tarybos finansuojamą projektą „Atsinaujinančių energijos išteklių ekonominio skatinimo pagrindimas" tikimès pademonstruoti, kokią naudą visuomenei teiktų platesnis saulès energijos panaudojimas ir parengti rekomendacijas dèl ekonominès bei finansinès paramos, siekiantiems ịsirengti saulès kolektorius.

Atlikti tyrimai rodo [7, 8], kad nuo gegužès iki spalio mèn. Lietuvoje yra galimybès saulès kolektoriais šildyti vandeni buitiniams poreikiams iki $50-70{ }^{\circ} \mathrm{C}$. Kitais mènesiais saulès spinduliuotè nèra tokia intensyvi, tačiau ir 
šalčiausiomis, bet saulètomis dienomis šaltas vandentiekio vanduo, eksploatuojant dviejų kontūrų saulès karšto vandens šildymo sistemą (saulès sistemos kontūras užpildomas neužšąlančiu skysčiu - antifrizu (propilenglikolio mišiniu), gali būti pašildomas iki $15-45^{\circ} \mathrm{C}$. Tai reiškia, kad tuo šaltu metų laiku reikès naudoti mažiau iškastinio kuro karštam vandeniui ruošti.

Labiausiai socialiniu ir ekonominiu požiūriu probleminè sritis - daugiabučiai namai - kuri beveik netyrinèta.

Apibendrinant informaciją apie saulès kolektorius buvo prieita išvados, kad saulès kolektoriai labiausiai tinka šildyti vandenị. Numatoma sąlyga, jog dèl sudètingos sistemos, reikalingų talpų šilumai akumuliuoti, saulès kolektoriai bus naudojami ruošti karštą vandenį tik daugiabučiui namui.

Šilumos kiekis, kuris panaudojamas karštam vandeniui, turi būti kuo tolygiau pasiskirstęs per parą ir metus. Ši sąlyga teikia ekonomini pranašumą daugiabučiams namams. Todèl daugiabučiame name pagamintos ir sunaudotos šilumos vieneto kaina gali būti mažesnè nei individualiame name. Deja, kiekvienu konkrečiu atveju galimi ịvairūs niuansai, kuriuos reikia iš anksto numatyti ir ịvertinti nustatant šilumos, pagamintos naudojant saulès energiją, kainą.

Labai padrąsinantis ženklas, kad jau antras daugiabutis namas Panevežyje įsirengè saulès kolektorius gaminti karštą vandenị. Tai naujas ir reikšmingas praktinis žingsnis, galintis labai pagelbèti plečiant saulès energijos panaudojimą ir ypač tikslingai nukreipti tyrimus. Nors mūsų šalyje kelios dešimtys firmų platina ịvairių užsienio įmonių saulès kolektorius, tačiau pagrindinis rinkos segmentas - daugiabučiai namai - vis dar lieka tarsi „užribyje“.

Teoriškai galima teigti, kad centralizuoto šildymo sistemos perspektyvinės raidos scenarijų sudètyje gali figūruoti ne tik biokuro katilinès, bet ir šimtai, gal net tūkstančiai „saulès katilinių", t. y. - saulès kolektorių, irengtų tiek daugiabučiuose, tiek ir individualiuose namuose. Nebūtinai šie kolektoriai turètų būti vartotojų nuosavybè. Mažai tikètina, kad naujų generatorių atsiradimas pablogintų CŠT ekonominę padètị. Sprendžiant kainodaros klausimus įmanoma, jog to paties centrinio šildymo raidos scenarijuje gali figūruoti ir namo šiluminè renovacija. Šie kolektoriai dabartinių kainų požiūriu realiausiai gali pretenduoti ị dalị karšto vandens ruošimui skiriamo galingumo. Dabartiniu laikotarpiu pagrindine problema, kuri užtveria kelią tokio pobūdžio scenarijų sampratai, yra ne tiek techninè ar teisinè, bet vis griežtejjanti takoskyra tarp šilumos tiekèjų ir vartotojų.

Svarbu, kad pirkèjams būtų pateikiama išsami ir teisinga informacija apie saulès karšto vandens šildymo sistemas bei jų atskirų elementų teigiamus ir neigiamus aspektus. Šių sistemų $1 \mathrm{~m}^{2}$ instaliavimo kaina yra pakankamai aukšta ir gali siekti keletą tūkstančiu litų (priklausomai nuo gaminio kokybės). Dauguma kolektorių tiekèjų pagal užsakovų deklaruotą karšto vandens sunaudojimą pateikia išankstinius rekomenduojamus sistemų dydžius. Daug platesnę, išsames- nę informaciją galima nustatyti specializuotomis Polysun, $\mathrm{T}^{\star} \mathrm{SOL}$ ir kt. programomis. Modeliuojama ịvertinus karšto vandens poreikị, plokščių ar vakuuminių saulès kolektorių darbo trukmę per metus, jų efektyvumą. Priklausomai nuo saulès kolektoriaus tipo, jo ploto, šilumos nuostolių ir kt. parametrų pateikiama saulès kolektoriuje pagaminto karšto vandens energijos kaina, sistemos atsipirkimo laikas ir kt.

Nèra vieno kolektoriaus, kuris galètų būti ịvardijamas kaip „efektyviausias“, kadangi efektyvumas priklauso nuo jų panaudojimo paskirties. Sezoniniam plaukimo baseino vandens šildymui visiškai tinka ultravioletiniams spinduliams atsparus plastikinis saulès kolektorius. Apsauginès skaidrios dangos šis kolektorius neturi, nes naudojamas šviečiant saulei. Šilumos akumuliatoriumi šioje sistemoje yra pats baseinas. Priklausomai nuo pasirinkto kolektoriu dydžio, sušildo vandenị iki $20-30^{\circ} \mathrm{C}$.

Kai reikalinga aukštesnè darbo temperatūra, naudojami plokštieji ar vakuuminiai kolektoriai. Jie skiriasi pagal saulès spindulius sugeriančiu elementu gamybos technologiją. Plokštieji, sudarantys 70-80 \% visų pasaulyje veikiančiu kolektorių, saulès energiją transformuoja ị šilumą iš esmès tik esant tiesioginiam spinduliavimui. Saulès šviesą absorbuojanti plokštė padengiama titano oksido, juodo chromo ar nikelio dangomis su aukštais absorbcijos ir emisijos koeficientais, o kolektoriaus viršus uždengiamas ypač pralaidžiu saulès spinduliams $4 \mathrm{~mm}$ storio antirefleksiniu, prizminiu ir grūdintu stiklu. Šis kolektorius turi pakankamai gerą šiluminę izoliaciją iš apačios ir šonų.

Vakuuminiai kolektoriai - tai pačios naujausios kartos irenginiai, turintys dideli efektyvumą pasiekiančius vakuuminius elementus. Jie šiluma paverčia ir dalį išsklaidytos saulès spindulių energijos (veikia ir apniukusiu oru). Pagal veikimo principą šio tipo kolektoriai skirstomi $i \underline{i}$,tiesioginio pratekejjimo“ ar „šiluminio vamzdelio“. Pirmojo tipo kolektoriuose vakuuminiame vamzdyje patalpintas metalinis absorberis, kaip ir plokščiame kolektoriuje, padengtas dangomis, turinčiomis efektyvius saulès absorbcijos ir emisijos rodiklius. Jis sukauptą šilumą perduoda šildomam skysčiui. Kitos konstrukcijos pagrindinis šilumą generuojantis elementas yra šiluminis vamzdelis, kuris efektyviai šilumą perduoda šildomam skysčiui. Tai uždaras vamzdelis, turintis mažai lengvai užverdančio skysčio. Veikiamas šilumos, skystis garuoja, pasiimdamas vakuuminio vamzdelio šilumą. Garai kyla į viršų, kondensuojasi ir perduoda šilumą pagrindinio šildymo kontūro skysčiui. Kondensatas suteka žemyn, ciklas kartojasi. Tokia vakuuminio (su šiluminiu vamzdeliu viduje) saulès energiją sugeriančio elemento konstrukcija yra labai efektyvi, ilgaamžè, atspari temperatūroms iki $+300^{\circ} \mathrm{C}$.

Saulès kolektorių sistemos gali būti montuojamos visu tipų pastatuose - individualiuose namuose, daugiabučiuose, visuomeninès paskirties ar pramoniniuose pastatuose, kur reikalingas karštas vanduo. Ypač didelị ekonomini 
efektyvumą galima pasiekti montuojant didelès apimties sistemas. Tuomet sistemų $1 \mathrm{~m}^{2}$ instaliavimo kaina, taip pat atsipirkimo laikas tampa labiau priimtinas.

Daugiametė užsienio šalių kolektorių eksploatavimo patirtis rodo, kad plokštieji kolektoriai tarnauja apie 2025 metus, o vakuuminiai - 15-20 metus.

Priklausomai nuo gamintojo, perkamų kolektorių kiekio ar ploto vakuuminių kolektorių $1 \mathrm{~m}^{2}$ kaina yra 20-30\% aukštesnè nei plokščiojo.

Ekonominis Saulès šiluminès energijos išteklių panaudojimo vertinimas sugretinamos energijos kainos metodu

Norėdami kiek immanoma tiksliau ir realiau nustatyti tikrąsias saulès panaudojimo galimybes bei prielaidas (kurioms esant būtų galima tikètis didesnès saulès energijos panaudojimo technologijų paklausos), parinkome konkretų daugiabuti namą Kauno mieste: Saulès g., 5 aukštai, 70 butų, namas pastatytas 1978 m. Jei gyventojai nuspręstų tvarkyti šilumos ūkį neatsijungdami nuo miesto centralizuoto šilumos tiekimo tinklo, ant lygaus stogo ploto reikètu pastatyti saulès kolektorius, kurie ir tiektų namui šilumą karšto vandens ruošimui.

1 lentelëje pateikti duomenys, surinkti iš asmeninių gyventojų sąskaitų, pateiktų „Kauno energijos“ nuo 2009 m. gruodžio mèn. iki 2010 m. lapkričio mèn. Dabartinè šilumos kaina Kaune yra 31 ct/kWh (su PVM).

\section{Projekto investicijos}

Skaičiavimus atlikome pagal vykdomą projektą MIP2011/007. Projekto dèka turèjome galimybę issigyti skaičiavimų programas Polysun, $\mathrm{T}^{\star} \mathrm{SOL}$. Jose yra sukaupta didelè informacinè bazé, kuri leidžia patikimai nustatyti pagrindinę informaciją, reikalingą techniniams ir ekonominiams skaičiavimams. Modeliavimas vykdomas ivvertinus karšto vandens poreikị, plokščių ar vakuuminių saulès kolektorių darbo trukmę per metus, jų efektyvumą (2 pav.). Priklausomai nuo saulès kolektoriaus tipo,

1 lentelè. Daugiabučio namo šilumos suvartojimas 2009 12-2010 11 laikotarpiu

\begin{tabular}{|c|c|c|c|c|}
\hline \multirow{2}{*}{ Mènuo } & \multicolumn{3}{|c|}{ Sunaudota šiluma } & \multirow{2}{*}{$\begin{array}{c}\text { Bendras (naudingas) } \\
\text { plotas } \mathrm{m}^{2}\end{array}$} \\
\hline & Šildymui kWh & Karštam vandeniui kWh & Šilumos kiekis $\mathrm{kWh} / \mathrm{m}^{2}$ & \\
\hline Gruodis & 78150,92 & 21609,08 & 20,50 & 3811,96 \\
\hline Sausis & 124554,74 & 19945,26 & 32,67 & \\
\hline Vasaris & 95428,62 & 1994,38 & 25,03 & \\
\hline Kovas & 77357,74 & 19792,26 & 20,29 & \\
\hline Balandis & 18538,20 & 19411,80 & 4,86 & \\
\hline Gegužè & 0 & 17026,48 & 0 & \\
\hline Birželis & 0 & 19377,12 & 0 & \\
\hline Liepa & 0 & 18039,97 & 0 & \\
\hline Rugpjūtis & 0 & 18119,97 & 0 & \\
\hline Rugsèjis & 0 & 23920,02 & 0 & \\
\hline Spalis & 45446,74 & 18823,26 & 11,92 & \\
\hline Lapkritis & 62092,00 & 18198,00 & 16,29 & \\
\hline Iš viso: & 501568,96 & 216257,6 & 131,58 & \\
\hline
\end{tabular}

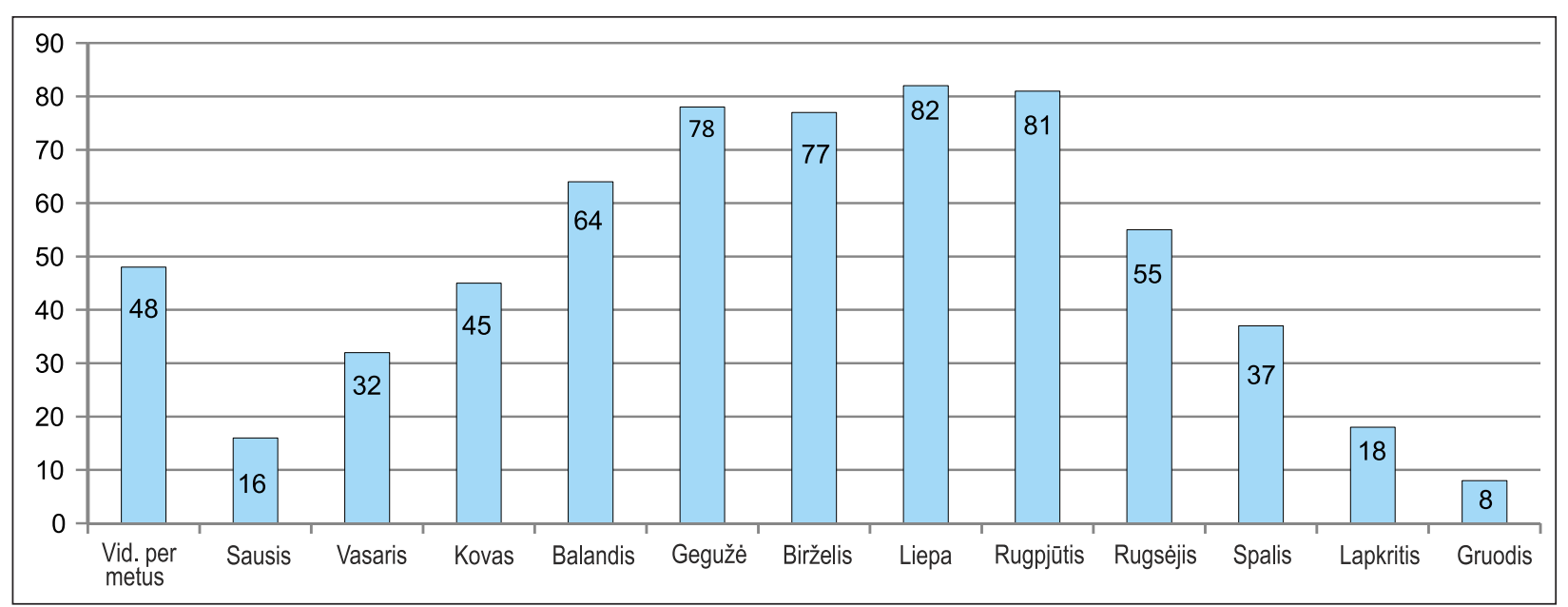

2 pav. Saulès energijos panaudojimo galimybių pasiskirstymas mėnesiais, procentais nuo bendro šilumos kiekio

Šaltinis: sudaryta šio straipsnio autorių naudojant Polysun programą. 
jo ploto, šilumos nuostolių parametrų pateikiama saulès kolektoriuje pagaminto karšto vandens energijos kaina, sistemos atsipirkimo laikas ir kt.

Specializuotos programos ịvertina saulès energijos pagaminto karšto vandens sistemos teorines galimybes, kurios dažnai labai skiriasi nuo realaus gyvenimo sąlygų. Galime teigti, kad saulès karšto vandens ruošimo sistemų efektyvumas priklauso ne nuo skaičiavimo programa nustatyto šiluminès energijos kiekio kolektoriuose, o kokị energijos kiekị mes realiai panaudojame (2 lentelè), kuris, ruošiant karštą vandenį tiek plokščiaisiais, tiek vakuuminiais kolektoriais, Lietuvoje svyruoja nuo 330 iki $580 \mathrm{kWh} / \mathrm{m}^{2}$.

\section{Eksploatacinès išlaidos}

Siekiant užtikrinti planuojamą saulès kolektoriu šilumos gamybą, būtina bent kartą per metus juos nuvalyti. Išlaidos aukštalipiams samdyti gali sudaryti apie $1000 \mathrm{Lt} /$ metus. Išlaidas didina kas 5 metus keičiamas sistemos kontūre neužšąlantis šilumnešio saulès kolektorius (nepakeitus iškyla užšalimo grėsmè). Nagrinėjamai sistemai propilenglikolio reikètu apie $160 \mathrm{l}$, vadinasi, išlaidos siektų 3200 Lt (arba $640 \mathrm{Lt} /$ metus).

Pagrindine metinių finansinių išlaidų dedamąja yra amortizaciniai atskaitymai (3 lentelè). Jų dydis priklauso nuo investicijų irrengimams ir nuo jų tarnavimo laiko. Visas eksploatacines išlaidas ịvertinome dviem būdais: 1) kai namas pasigamina $40 \%$ šilumos karštam vandeniui, suma siekia 5400 Lt per metus; 2) $50 \%$ - 7400 Lt per metus.

Sugretinamos energijos kaina nustatoma šiais variantais:

1. Gyventojai ịrengia kolektorių savomis lěšomis bei paskolomis be subsidijų.

2. Pagal daugiabučiu renovavimo programą teikiama $15 \%$ subsidija investicijoms.

3. Hipotetiškai priimame, kad pagal daugiabučių programą ir aplinkosaugines programas teikiama $50 \%$ subsidija investicijoms.

Trūkstamą karšto vandens ruošimui reikiamą šilumos kiekị gausime iš CŠT už $31 \mathrm{ct} / \mathrm{kWh}$.

2 lentelè. Saulès kolektorių sistemos karšto vandens ruošimui investicijų pagrindimas

Sąmata-specifikacija (preliminari)*

\begin{tabular}{|c|c|c|c|}
\hline \multirow[t]{2}{*}{ Eil. Nr. } & \multirow{2}{*}{$\begin{array}{l}\text { Irengimų ir medžiagu } \\
\text { pavadinimas }\end{array}$} & \multicolumn{2}{|c|}{$\begin{array}{c}\text { Saulès kolektorių sistemos paruoštas karštas vanduo } \\
\text { (nuo bendro poreikio) }\end{array}$} \\
\hline & & $40 \%$ & $50 \%$ \\
\hline \multirow[t]{2}{*}{1} & $\begin{array}{l}\text { Saulès kolektorių sistema karšto vandens ruošimui: } \\
\text { 1. Plokštieji saulès kolektoriai } \\
\text { 2. Montavimo elementų komplektas } \\
\text { 3. Akumuliacinis vandens šildytuvas su vienu šilumokaičiu } \\
\text { 4. Siurblio modulis } \\
\text { 5. Valdymo automatika } \\
\text { 6. Membraninis išsiplètimo indas }\end{array}$ & & \\
\hline & Iš viso Lt (be PVM): & 269320 & 369889 \\
\hline 2 & Papildomos medžiagos saulès kolektorių sistemos montažui & 13466 & 18494 \\
\hline 3 & Projektavimo darbai & 8080 & 11097 \\
\hline \multirow[t]{4}{*}{4} & Montavimo, derinimo darbai & 53864 & 73978 \\
\hline & Iš viso Lt (be PVM): & 344729 & 473458 \\
\hline & PVM $21 \%$ : & 72393 & 99426 \\
\hline & Iš viso Lt (su PVM): & 417122 & 572884 \\
\hline
\end{tabular}

* Pažymètina, kad skaičiai gauti Polysun programa, tačiau praktiškai igyvendintuose 2 daugiabučių namų projektuose Panevežyje investicijų dydžiai yra daug mažesni.

3 lentelè. SEK skaičiavimų suvestineं*

\begin{tabular}{|c|c|c|}
\hline Diskonto normos ir subsidijos lygis & $40 \%$ karšto vandens $\mathrm{Lt} / \mathrm{kWh}$ & $50 \%$ karšto vandens Lt/kWh \\
\hline \multicolumn{3}{|l|}{ 1. SEK esant $4 \%$ diskonto normai } \\
\hline 1.1. Be subsidiju & 0,40 & 0,44 \\
\hline 1.2. Su $15 \%$ subsidija & 0,35 & 0,39 \\
\hline 1.3. Su $50 \%$ subsidija & 0,23 & 0,26 \\
\hline \multicolumn{3}{|l|}{ 2. SEK esant $7 \%$ diskonto normai } \\
\hline 2.1. Be subsidiju & 0,49 & 0,54 \\
\hline 2.2. Su $15 \%$ subsidija & 0,42 & 0,47 \\
\hline 2.3. Su $50 \%$ subsidija & 0,27 & 0,3 \\
\hline
\end{tabular}

* Tolimesni tyrimai parodys, kokiu mastu teoriniai investicijų dydžiai gali būti sumažinti atsižvelgiant į faktinius igyvendintų projektų duomenis. Atitinkamai koreguosis ir sugretinamų energijos kainų dydžiai. 
Jeigu saulès energijos kaštus lygintume su karšto vandens ruošimu panaudojant gamtines dujas, tuomet būtų sutaupoma $15315 \mathrm{~m}^{3}$ gamtinių dujų, vadinasi, išvengtume jų deginimo (sumažintume $37238 \mathrm{~kg}$ ), $\mathfrak{i}$ atmosferą nepatektų apie $37 \mathrm{t} \mathrm{CO}_{2}$. Galima apibendrinant teigti, kad esamomis sąlygomis saulès energijos panaudojimas ekonominiu požiūriu pavieniams vartotojams dar nèra priimtinas. Tik apie 30-50 \% kompensacijos už investicijas galètu paskatinti gyventojus aktyviau naudoti saulès energiją. Tačiau galima tvirtai pasakyti, kad kaina nẻra griežtai nekintamas dydis. Ji yra tam tikra įvairių sąlygų projekcija ir gali labai skirtis (priklauso nuo paramos dydžio).

Gauti rezultatai yra atspirties taškas apmąstymams ir išvadoms. Jas galima "pakreipti“ norima linkme, kas paprastai ir yra daroma. Mūsų tikslas - pateikti maksimaliai objektyvią informaciją nenuslepiant problemų. O jų yra ir gali atsirasti daugiau nei įmanoma numatyti. Pvz., tikètina, kad ne visu esamų pastatu šilumos punktuose galima imontuoti akumuliacines talpas. Tačiau dviejuose namuose Panevėžyje tai buvo igyvendinta, todèl galima tikètis, kad immanoma išspręsti šią techninę problemą.

Siekiant išvengti vandens užteršimo, o taip pat Legionella bakterijų atsiradimo, būtina saulès karšto vandens ruošimo sistemą įrengti pagal būtinus saugaus eksploatavimo reikalavimus. Tai ypač aktualu, kai sistema yra užpildoma vandeniu iš atvirų vandens baseinų [9].

Lietuvoje ịvertinus saulès kolektorinių sistemų rinkos augimo tendencijas ir išanalizavus naujai projektuojamų gyvenamųjų namų kvartalų ir visuomeniniu pastatų projektus, energijos kainų kitimo tendencijas, o taip pat kaimyninių šalių pasiekimus, galima konstatuoti, kad šios energijos panaudojimas ateityje turètų didèti.

\section{NACIONALINIŲ ENERGIJOS PLĖTROS RODIK- LIU IR ISIPAREIGOJIMU IGYVENDINIMO PROBLEMOS BEI JŲ SPRENDIMO GALIMYBĖS}

Pagrindinè problema yra sukurti jungtị tarp strateginių sprendimų, kurie priimami valstybès lygiu per teritorinius vienetus - regionus (apskritis arba stambesnius regionus), miestus, rajonus - iki galutinių vartotojų.

Aptarsime dvi svarbias direktyvas, kurios dèl skuboto igyvendinimo sukelia didžiuli spaudimą, reikalauja labai didelių išlaidų ir tiesiogiai daro įtaką ypač skausmingas problemas išgyvenančiam centralizuoto šilumos tiekimo sektoriui bei namų ūkiams.

Taršos integruotos prevencijos ir kontrolès (TIPK) direktyva (2010/75/ES) sugriežtina teršalų, išmetamų iš didelių kurą deginančių įrenginių, normą po 2016 metų. Šie reikalavimai yra kur kas griežtesni už šiuo metu galiojančias normas: leistina sieros junginių $\left(\mathrm{SO}_{2}\right)$ koncentracija dūmuose mažinama 2-5 kartus, azoto oksidų (NOx) - 2-3 kartus, griežtinamos ir kietųjų dalelių išmetimo normos. TIPK di- rektyvos igyvendinimas ne tik pareikalaus naujų degiklių katiluose, bet reikès įdiegti ir gana brangius dūmų valymo technologinius irrenginius mazutą ir gamtines dujas deginančiuose energetikos objektuose. Mažiau teršalų turès būti išmetama ir iš biomasę deginančių katilų, bet tai pasiekti paprasčiau, nes jau dabar tokie įrenginiai turi kietųjų dalelių valymo filtrus, o išmetami dūmai paprastai „praplaunami“ kondensaciniuose ekonomaizeriuose ar rekuperatoriuose.

Didžiosios elektrinès Vilniuje, Kaune ir Mažeikiuose privalès reikalavimus igyvendinti ne vèliau kaip 2016 metais, nes joms jau buvo atidètas taršos reikalavimų i̇diegimo terminas.

Jeigu šituose miestuose ir toliau išliktu esami šilumos generavimo įrenginiai, kad atitiktų TIPK direktyvas, reikètų įrengti aplinkosauginių priemonių. Bendras investicijų poreikis Lietuvos CŠT sektoriuje direktyvos 2010/75/ES igyvendinimui būtų apie $1,98 \mathrm{mlrd}$. Lt, jeigu iš esmès nekistų technologijos ir dabar naudojamo kuro balansas [1].

2009 m. balandžio 23 d. Europos Parlamento ir Tarybos direktyva 2009/28/EB dèl skatinimo naudoti atsinaujinančių išteklių energiją nustatė valstybèms narèms atsinaujinančiu išteklių energijos naudojimo privalomus bendruosius nacionalinius planinius rodiklius. Lietuvos Respublika privalo užtikrinti, kad atsinaujinančiu išteklių energijos dalis bendrame energijos suvartojimo balanse 2020 metais siektų ne mažiau kaip $23 \%$ [11].

Europos Sajungos teisès reikalavimus atsinaujinančiu išteklių energetikos srityje ị Lietuvos Respublikos nacionalinę teisę perkeliantis Lietuvos Respublikos atsinaujinančiu išteklių energetikos įstatymas, kuriuo nustatomi atsinaujinančiu išteklių energetikos sektoriaus valstybinio valdymo, reglamentavimo, priežiūros ir kontrolès bei veiklos atsinaujinančių išteklių energetikos sektoriuje organizavimo teisiniai pagrindai, numato šiuos rodiklius atskiruose sektoriuose, kurie turi būti pasiekti 2020 metais.

Jau nuo 2009 metų prièmus ES direktyvą prasidèjo intensyvus debatų, tyrimų ir teisinès bazès formavimo procesas, kurio reikšmingas ir svarus rezultatas 2011 metais yra priimtas atsinaujinančiu energijos ištekliu įstatymas. Šiuo metu yra parengta ir diskutuojama Nacionaline atsinaujinančių energijos išteklių plètros programa, kurioje numatoma centralizuotai tiekiamos šilumos energijos, pagamintos iš atsinaujinančių energijos išteklių, dali šilumos energijos balanse padidinti ne mažiau kaip iki $60 \%$, o namų ūkiuose atsinaujinančių energijos išteklių dali šildymui sunaudojamų energijos išteklių balanse padidinti ne mažiau kaip iki $80 \%$.

Atsinaujinančių energijos išteklių panaudojimas centralizuotai tiekiamai šilumos energijai gaminti galètų būti decentralizuojant šilumos gamybą, sprendžiant nepriklausomų šilumos gamintojų prijungimo prie šilumos tinklų problemas, sureguliuojant iš atsinaujinančiu energijos išteklių pagamintos šilumos energijos supirkimą ir kitomis 
priemonėmis skatinant atsinaujinančių energijos išteklių naudojimą šilumos energijai gaminti.

Viena iš galimybių, kurią mes analizuojame, būtų saulès energijos panaudojimas karšto vandens ruošimui daugiabučiuose namuose. Pagal naująją Daugiabučiu namų atnaujinimo (modernizavimo) programą valstybé remia (Vyriausybės nustatyta tvarka kompensuojama $15 \%$ investicijų) energini efektyvumą didinančias priemones. Tarp jų ir atsinaujinančios energijos šaltinių (saulès, vėjo ir t. t.) įrangos finansavimas. Naujai statomuose namuose galima be kliūčių suprojektuoti ir ịrengti saulès kolektorius karštam vandeniui ruošti. Tai įmanoma ir esamuose senos statybos pastatuose. Pagrindinis ir svarbiausias veiksnys, lemiantis saulès energijos panaudojimą karštam vandeniui ruošti, yra riboti finansiniai ištekliai.

Saulès kolektorius galima statyti ant pastato stogo, pritvirtinti prie sienos ar montuoti ant žemés paviršiaus. Svarbu, kad kuo daugiau saulès spinduliuotes patektu i kolektoriaus paviršių. 4 lentelejje pateikti duomenys rodo, kad 50,2 \% visi būstai karštu vandeniu aprūpinami centralizuotai iš miesto (rajono) šilumos tinklų (miestas - 71,3\%, kaimas $-2,5 \%$ ) ir 1,6\% centralizuotai iš vietinès katilinès (miestas $-2,17 \%$, kaimas - 0,6\%).

Tenka konstatuoti, kad individualiai karštu vandeniu apsirūpina 31,2 \% būstų, o 7,2 \% miesto ir 41,6 \% kaimo gyventojų iš viso neturi karšto vandens ruošimo įrenginių. Tai dideli skaičiai ir jie verčia susimąstyti, ịvertinti susidariusią situaciją ir teikti rekomendacijas, gerinančias socialinę padètị kaime. Idealiausia būtų ịsirengti pramoninę saulès karšto vandens tiekimo sistemą. Jos panaudojimo klausimai buvo išsamiai išnagrinèti $[9,10]$.

5 lentelèje pateikiami rezultatai apie karšto vandens ruošimo ịrenginius ir naudojamo kuro bei energijos rūšis.
Didžioji dalis (51,8\%) karšto vandens ruošimui naudojamos energijos - tai šilumine energija iš miesto (rajono) šilumos tinklų. Antroje vietoje - 16,6 \% - malkos ir kurui skirtos medienos atliekos kombinuotame šildymo sistemos katile su karšto vandens šildytuvu ir 14,6 \% - elektros energija, naudojama vandens šildytuve.

Ne mažiau svarbus yra vadybinis aspektas. Teritoriniai valstybės valdymo padaliniai: savivaldybės arba jų ịsteigtos / steigiamos energetikos plètros agentūros turi būti vadybininkais bei organizatoriais, atsakingais už teritorinio rajono, miesto, regiono, o tuo pačiu ir valstybès įsipareigojimų vykdymą.

Miesto energetikos pažangos tikslai, orientyrai gali būti imanomi igyvendinti tik tokiu atveju, jeigu yra organizuojama esamos būklès analizè. Turi būti teisinè prievolè organizuoti energetikos raidą nacionaliniu mastu paskirstomy rodiklių igyvendinimą vietiniu (miestų, rajonų, regionų) lygiu. Neigiamu pavyzdžiu gali būti stichiškai priimami sprendimai naikinti šilumos tinklus pabrangus dujoms ir masiškai statyti individualias biokuro katilines. Tinklų infrastruktūrą galima panaudoti AEI technologiniams sprendimams. Užsienio šalyse vyksta intensyvūs tyrimo bei eksperimentiniai darbai, šia linkme siekiant ateityje optimaliai panaudoti esamą infrastruktūrą [13, 14].

Galima pateikti pavyzdį, kaip šis procesas yra organizuotas Olandijoje. Pagal vykdomą ir finansuojamą $\mathrm{Ny}$ derlandų valstybès projektą "Climate menu“ miestai gali pasirinkti sritis, kurioms teikia išskirtinị dėmesį vykdant valstybės prisiimtus įsipareigojimus. Aplinkosauginę politiką (išsamesnè informacija: www.climatemenu.com) realizuoja miestai, nes būtent juose ir koncentruojasi galimybès bei išryškèja problemos. Savivaldybei skiriamos subsidijos dydis priklauso nuo jos dydžio ir gyventojų skaičiaus,

4 lentelè. Būstai pagal aprūpinimo karštu vandeniu būdą (\% nuo bendro būstų skaičiaus) [12]

\begin{tabular}{c|ccc}
\hline & Iš viso & Miestas & Kaimas \\
\hline Aprūpinti karštu vandeniu centralizuotai iš miesto (rajono) šilumos tinklų & 50,2 & 71,3 & 2,5 \\
\hline Aprūpinti karštu vandeniu centralizuotai iš vietinės katilinės & 1,6 & 2,1 & 0,6 \\
\hline Aprūpinti karštu vandeniu iš individualių šildymo sistemu & 31,2 & 20,4 & 55,8 \\
\hline Būstai, neturintys karšto vandens & 17,8 & 7,2 & 41,6 \\
\hline
\end{tabular}

5 Ientelè. Būstai pagal karšto vandens ruošimo įrenginius ir naudojamo kuro bei energijos rūšis (\% nuo bendro būstų skaičiaus) [12]

\begin{tabular}{c|c|c}
\hline & $\begin{array}{c}\text { Kombinuotas šildymo } \\
\text { sistemos katilas su karšto } \\
\text { vandens šildytuvu }\end{array}$ & $\begin{array}{c}\text { Vandens } \\
\text { šildytuvas } \\
\text { (rajono) šilumos tinklų }\end{array}$ \\
\hline Elektros energija & 14,6 \\
\hline Gamtinès dujos & 4,1 & 1,2 \\
\hline Suskystintos naftos dujos & 0,1 & 0,2 \\
\hline Skystasis kuras & 0 & 0 \\
\hline Šilumine energija & 3,8 & 0,7 \\
\hline Akmens anglys & 16,6 & 2,5 \\
\hline Malkos ir kurui skirtos medienos atliekos & 1,9 & 0,3 \\
\hline Kitas kuras & & 51,8 \\
\hline
\end{tabular}


todèl mažesnės savivaldybės kooperuojasi ir vykdo bendrus projektus, taip sutaupo dali pinigų (išsamesnè informacija: www.senternovem.nl - Olandijos energetikos agentūros (SenterNovem agentūros) tinklapyje).

Olandijoje yra apie 500 savivaldybių, iš kurių apie 300 jau pasinaudojo parama. Kiekvienas miestas priklausomai nuo dydžio, organizuotumo ir specifinès problematikos gali pasirinkti savas sritis.

Skiriama parama projektų igyvendinimui iš valstybès subsidijų gali būti finansuojama $50 \%$ projekto iggyvendinimo išlaidų, o likusią dalį sumoka savivaldybè. Kiekviena savivaldybe savo nuožiūra pasirenka finansavimo sritis.

Yra trys tikslų lygiai, kurie parodo, kokia apimtimi savivaldybè nori plètoti finansuojamą sriț. Valstybès finansuojamas projektas turi būti igyvendintas per ketverius metus.

Mokslinė problema yra teisingas AEI socialinio naudingumo ịvertinimas, kuris gali parodyti tuos pranašumus, kurie neịvertinami investiciniuose sprendimuose, pvz., AEI neišsenkamumą ir tuo pačiu galimybę užtikrinti ateities kartoms apsirūpinimą energijos ištekliais. Kai kurios AEI technologijos, pvz., saulès energijos panaudojimas kartu sprendžia ir aplinkosaugos problemas, taigi, gali būti papildomai finansuojamas iš kitų šaltinių. Tam reikalingos visapusiškos žinios, ju koordinuota visuma ir tikslingas žiniu perteikimas. Sprendimas negali būti vienareikšmiškai nusakytas, kadangi pati problema yra įvairialypè.

\section{IŠVADOS}

1. Atsinaujinančios energijos išteklių panaudojimo mastai ir kryptys gali priklausyti nuo vyriausybinių programų prisiimtų ịsipareigojimų ir sprendimų. Tuo būdu formuojami finansavimo, ypač struktūrinių fondų panaudojimo, supirkimo tarifų ir kitu energetikos politikos ịgyvendinimo instrumentų sprendimai.

2. Didelis saules energijos panaudojimo potencialas glūdi daugiabučių namų sektoriuje. Ši potencialą galima realizuoti renovuojant daugiabučius pastatus, kartu modernizuojant ir pastatų šilumos ūkị. Saulès kolektorių panaudojimas karšto vandens gaminimui daugiabučiuose namuose šiuo metu yra viena iš perspektyviausiu krypčių, jos potencialas vertinamas iki $40 \%$ karštam vandeniui reikiamo šilumos kiekio.

3. Ekonominị konkurencingumą ịvertiname sugretinamos energijos SEK kainos metodu. Galima teigti, kad Daugiabučių namų renovavimo programos rèmuose modernizuojant šilumos ūkị, daugelyje miestų saulès energijos panaudojimas karštam vandeniui pasigaminti būtų konkurencingas net be papildomos paramos.

4. Saulès energijos panaudojimas kartu sprendžia ir aplinkosaugos problemas, todèl gali būti papildomai finan- suojamas iš kitų šaltinių. Papildoma parama turètų būti grindžiama tuo, kad saulès energijos panaudojimas akivaizdžiai prisidètų sprendžiant ES direktyvų igyvendinimo klausimus. Akivaizdu, kad tikslingiausia parama būtų subsidijos investicijoms, lengvatinès paskolos. Paramos dydis turi būti pagrịstas naudingumu visuomenei.

\section{PADE்KA}

Autoriai dèkoja Lietuvos mokslo tarybai, finansuojančiai mokslininku iniciatyva parengtą projektą MIP-007/2011, kurio pagrindu yra atliekami tyrimai.

Gauta 20120515

Priimta 20120817

\section{Literatūra}

1. Lukoševičius V., Balaišyte B. Centralizuotai tiekiamos šilumos kainų Lietuvos savivaldybese priežastingumo tyrimas. 2011.

2. Klevas V., Biekša K., Klevienè A., Bubelienè J., Stankevičius M. Energetikos raidos darnumo vertinimo metodologijos principai. Energetika. 2010. T. 56. Nr. 2. P. 92-102.

3. Kavolèlis B. Savos ir pramoninès gamybos saulès kolektorių vandeniui šildyti palyginamieji tyrimai. Energetika. 1995. Nr. 1. P. 27-33.

4. Kavolèlis B. Savos gamybos saules kolektoriai vandeniui šildyti. VI „Energetikos agentūra“, Energijos taupymo programų direkcija. Vilnius, 1996. 35 p.

5. Perednis E. Pasyviosios pastato šildymo sistemos, naudojančios saulès energiją. Energetika. 1998. Nr. 2. P. 9398.

6. Perednis E. Investigation of potentialities of the passive solar heating systems. Proceedings of the Third ISES Europe Solar Congress: Eurosun 2000, 19-22 June 2000, Copenhagen, Denmark. P. 161-165.

7. Perednis E., Kavaliauskas A. Saulès energijos naudojimo šilumai gaminti Lietuvoje tyrimai. Energetika. 2005. Nr. 4. P. 49-53.

8. Katinas V., Vrubliauskas S., Savickas J., Perednis E. Atsinaujinantys energijos šaltiniai ir ju naudojimas Lietuvoje. Lietuvos mokslas. Lietuvos energetikos institutas 50. 2006. T. 61. P. 329-363.

9. Perednis E. Plokščiojo saulès kolektoriaus šiluminès ir hidrodinaminès charakteristikos. Energetika. 2004. Nr. 3. P. $60-65$

10. Perednis E., Kavaliauskas A., Plikšnienè V. Karšto vandens ruošimo naudojant sauless kolektorius efektyvumo tyrimai. Energetika. 2007. Nr. 1. P. 34-38.

11. $2009 \mathrm{~m}$. balandžio $23 \mathrm{~d}$. Europos Parlamento ir Tarybos direktyva 2009/28/EB dèl skatinimo naudoti 
atsinaujinančių išteklių energiją, iš dalies keičianti bei vèliau panaikinanti Direktyvas 2001/77/EB ir 2003/30/EB.

12. Energijos naudojimas namu ükiuose 2009. Statistikos departamentas. Vilnius. 2011. 27 p.

13. Gajbert H., Perers B., Karlsson B. Design and performance of a large solar thermal system with facade integrated collectors in several directions, connected to the district heating system. Proceedings of the 10th International Conference on Solar Energy at High Latitudes NORTH'SUN 2005, May 25, 2005, Vilnius, Lithuania. P. 1-4.

14. Futterlieb M. Solar Thermal Energy - Comparing Framework Conditions and Support Measures in the Renewable Heat Market of Germany and Spain. Proceedings of the ISES Solar World Congress, August 28 - September 2, 2011, Kassel, Germany. P. 1-14.

Audronė Klevienè, Eugenijus Perednis

\section{PRECONDITIONS OF INCREASING DEMAND FOR SOLAR ENERGY}

\section{Summary}

The analyses of assumptions for increasing solar energy demand have been provided. The main focus is to investigate what conditions are needed for thermal energy produced by users on the basis of solar technologies to compete with other energy sources. Conclusions have been made concerning on what scale and under what assumptions solar technologies may be competitive. The external utility may be the background for additional financing sources.

Key words: solar energy, methodological approach, economic evaluation of social utility
Аудроне Клявене, Эугениюс Переднис

\section{ПРЕДПОСЫЛКИ УВЕЛИЧЕНИЯ СПРОСА НА СОЛНЕЧНУЮ ЭНЕРГИЮ}

\section{Резюме}

Исследование представляет анализ предпосылок увеличения спроса на возобновляющиеся энергоресурсы на образце применения солнечной энергии. Акцентируется анализ экономической конкурентоспособности потребителей производящих тепловую энергию на основе солнечных технологий. Показывается в каких масштабах и на основе каких предпосылок солнечная энергия может конкурировать с другими энергетическими источниками. Общественной полезностью применения солнечной энергии определяется возможности финансирования.

Ключевые слова: солнечная энергия, методическое решение, экономическая оценка полезности 